\title{
Is atheism winning in Europe? The future of Christianity in the Western world
}

The main purpose of this article is to analyze the deep extinction of Christianity in Europe and to present the possibility of continuation of the Christian religion in those societies that are largely atheistic or agnostic. Atheism is undoubtedly a great challenge for the future. In some countries, today you can see the vision of the reality dominated by an atheistic culture and its worldview. Extremely interesting remarks on Christianity and an atheism can be found in the writings of the German philosopher Karl Rahner (1904-1984) and French mystic Madeleine Sémer (1874-1921). In the work of these two authors there is extremely penetrating diagnosis of the modern times and the prospect of transformation of the Christian religion in the Western world.

Key words: atheism, agnosticism, Christianity, Islam, nihilism, secularization, religious experience.

\section{Introduction}

In the work of Friedrich Nietzsche there is contained one of the most dramatic diagnoses of the modern world. In this context his comments on nihilism are particularly valuable. We could describe nihilism as a concept, doctrine or phenomenon, in which everything what exists beings, things, the world, as well as values and principles - is reduced to nothingness. Nihilism and nothingness are intertwined with each other and belong to each other. Therefore, we can say that nihilism is a whole thoughts, beliefs and behaviors, dominated by the concept 
of nothingness. At the end of the 19th century, Nietzsche wrote the following words:

I tell the story of the two next centuries. I describe the coming future,

Fundamental theology the future that can no longer come as different: the coming of nihilism.

This story we can tell right now: because it will be a work of necessity.

This future speakes already with hundreds of signs, this fate promises itself everywhere for this music of the future already everyone has sharp hearing. Our whole culture of Europe is moving already for a long time in tortures of tension, that increases century on century: uneasily, abruptly and strenuously: like a stream that wants to draw to an end, that no longer yields to reflection, that is afraid to reflect ${ }^{1}$.

In his work Thus Spake Zarathustra from 1883-1885 Nietzsche repeatedly uses the term "God is dead" - der Gott ist tot. This dramatic declaration can express the rejection of what is religious and Christian, but can also mean as certaitment of a tragic fate, that touches the modern age and the Western tradition ${ }^{2}$. The death of God is the image of the dissolution of foundation of our culture and morality, and of the loss of traditional values. For Nietzsche this image has become a kind of Ariadne's thread, which allows to go into a maze of our culture and to identify properly the main problems. The death of God is the end of traditional methaphisics and the end of faith in the objective world order, which would justify the fidelity to the truth under all circumstances.

Unfortunately, in recent years the diagnosis of Nietzsche becomes dramatically present in Europe and in the world. More and more often it is said about the extincion of Christianity in countries such as Germany, Denmark, Belgium or the Netherlands. In this context the difficult question arises about the possibility of further existence of Christian minorities in these societies, whose mentality is increasingly dominated by non-religious thinking. Remarkably interesting comments about this topic - can be found in the writings of the German thinker Karl Rahner (1904-1984) or French Mystic Madeleine Sémer (1874-1921). An extremely profound diagnosis of modern age and the prospects for the transformation of the Christian religion in the Western world are contained in the work of these authors.

1

F. Nietzsche, Zapiski o nihilizmie (1885-1889), [in:] Wokót nihilizmu, G. Sowiński ed., Kraków 2001, p. 103.

2 Cf. J. Żelazna, Narodziny nihilizmu - epoka mitu, epoka prawdy, „Toruński Przegląd Filozoficzny" 3/4 (2000), p. 57-81; R. Repole, Così parlò Nietzsche: Dio è morto?, „Archivio Teologico Torinese” 10 (2004) 1, p. 53-67. 
The main purpose of this article is to set out some of the signs of the extinction of Christianity in Europe and to show the possibilities for the further existence of Christian religion in these societies, which have been dominated by the attitude of religious indifference and by atheistic or agnostic thinking.

\section{Is God dead in Germany?}

On 7 November 2015, in the Italian opinion-forming magazine „Il Foglio Quotidiano", the journalist Giuglio Meotti published an article under the significant title Dio è morto in Germania ("God is dead in Germany") ${ }^{3}$. The author of this text gave the examples of the transformation of Protestant tamples into centres for refugees and immigrants in the country on the Rhine. So as not to offend the religious feelings of Muslims, crosses or fonts and other symbols od the Christian religion are removed from these churches. Catholics do the same. Giuglio Meotti gave the example of schools and the Catholic parishes of Düsseldorf, where lately a decision has been made to turn the traditional autumn Christian holiday of St Martin, celebrated for centuries on 11 November, into the "Festival of lights" (das Fest der Lichter), not to cause the alleged trauma in children of Muslim immigrants. Nanette Weidelt, Director of the Salesian School of Oberkassel, told the newpaper „Rheinische Post”, that the new name of the holiday will help in the integration of Muslim children in the German society.

In Germany we currently are facing the obvious marginalisation of the Christian religion in the public sphere. In the short term about $70 \%$ of German society may be total secularized ${ }^{4}$. More and more sociologist

Cf. G. Meotti, Dio è morto in Germania, „Il Foglio Quotidiano” 20 (2015) 264, p. 3. A similar diagnosis of the contemporary German society can be found in in the newest book by Rudolf Bauer. Cf. R. Bauer, Was ist los mit den Christen?, Trier 2013.

4 "In La festa è finita, lo scrittore Peter Hahne si domanda se «la Germania può ancora definirsi un paese cristiano o se non sarebbe più esatto dire che la Germania è un paese prevalentemente ateo dove convivono varie minoranze religiose».La cancelliera Merkel, a differenza dei suoi predecessori, non ha croci appese alle pareti dell'ufficio. Al massimo se ne trova una fra la Costituzione tedesca e le opere di Bertolt Brecht. Eppure, è la stessa Merkel ad aver detto: «Non è che abbiamo troppo islam, è che abbiamo poca cristianità». Un recente studio condotto alla University of Chicago dal sociologo Tom W. Smith rivela che i cittadini dell'ex Repubblica democratica tedesca hanno di gran lunga «il più alto tasso di ateismo al mondo». E Detlef Pollack, professore di Sociologia della religione all'Università di Münster, ritiene che la Germania orientale, con il suo ateismo dilagante, stia contagiando anche il resto del paese e che l'est sia diventato un cosiddetto «trendsetter», e predice che «almeno il 70 per cento 
Fundamental

or philosophers say about the birth in this country of "new atheism". (der neue Atheismus). Andreas Püttmann from the Konrad-Adenauer Foundation calls Germany "society without God" (Gesellschaft ohne Gott). Sociological studies show, that about 2030 less than 40 million inhabitants of the country on the Rhine will belong to all the Christian Churches. At the time, Christians will become formally a minority. Of course, the legal membership to the Church and church tax payment by Catholics or Protestants in many cases do not cancel out their atheism or agnosticism. In the axiological or conscientious sense we can say already today, that Christians in Germany are becoming a minority.

In the coming years it will have to be shut down half of the Christian temples in the country on the Rhine, which are at the moment gradually converted in restaurants, shops, hotels, congress centres, etc. In some cases, churches become masques. About 2020 the number of Muslims can reach 20 million. In the sense of the really practice of religion and the attitudes consistent with the professed religious doctrine, Germany may become soon the most Muslim populated country. There is increasing talk, that Germany is an atheistic country, in which live religious minorities. Very soon, the largest of these minorities will be Muslims.

About the practice of Christian faith in German society dominated by atheism also Joseph Ratzinger wrote in the 1970s. Ratzinger claimed that in the country upon the Rhine and in other Western societies, the Catholic Church and other Christian confessions will become a minority. National Churches will transform into a minority Church. That is a completely new situation, for which Catholics and Protestants must prepare. It is enough to give an example of countries such as Spain, Belgium or Ireland, to see the depth of the processes currently taking place there. The social position of Catholics in this countries is changing radically - the Catholic Church is receiving the minority status ${ }^{5}$. As a result, the Church will not be able to operate in the large organizational form that we know today, and it will have to live more modestly.

In the coming years in the country on the Rhine it will have to be shut down half of the Christian churches, which are now gradually being transformed into restaurants, shops, hotels, convention centers, etc. In some cases, churches have become mosques. A number of Muslims

delle persone in Germania» finirà per secolarizzarsi completamente" (G. Meotti, Dio è morto..., op. cit.).

$5 \quad$ Cf. J. Ratzinger, Sól ziemi. Chrześcijanstwo i Kościół katolicki na przełomie tysiącleci, transl. G. Sowiński, Kraków 1997, p. 218-236. 
can reach 20 million in 2020. In terms of practiced religion and attitudes consistent with the professed religious doctrine, Germany may soon become the country mostly Muslim. Increasingly, it is said that Germany is atheist country in which they live religious minorities. The largest of these minorities will soon be Muslims.

The practice of the Christian faith in a society dominated by atheism German wrote, among others, Joseph Ratzinger in the 70s of the last century. Ratzinger had already claimed that the country on the Rhine and in other Western societies, the Catholic Church and other Christian denominations will become a minority. Churches nationwide transform into minority churches. This is a completely new situation, to which Catholics and Protestants must prepare. Just to give an example of countries such as Spain, Belgium and Ireland, to see the depth of the processes currently taking place. Social position of Catholics is in these countries, radical changes - The Catholic Church receives the status of minorities. Consequently, she will not be able to continue to function in large organizational forms that we know today, and will have to live modestly.

When I wrote those words - reminded Joseph Ratzinger in 2001 - the accusations of pessimism came from all sides. And today nothing seems more forbidden than the so-called pessimism - which is often simply realism. Meanwhile, the majority admits that in the modern stage of the history of Europe the percentage of baptized Christians is clearly decreasing. In Magdeburg Christians make up only eight percent of the population - to emphasize: Christians of all denominations together. Statistics reflect the trend which cannot be put into question ${ }^{6}$.

December 28, 2014 the prestigious German weekly newspaper "Frankfurter Allgemeine Sonntagzeitung" published an article of a writer and a journalist Markus Günther entitled Kirche in der Krise: Diaspora Deutschland ("The Church in crisis: Germany diaspora")?. The author of this paper argues that in the country on the Rhine twilight of the Christian religion has begun: even if in the Catholic and Protestant Church there are still officially tens of millions of inhabitants in the vast majority of them can be talked about the evaporation of the central truths of the Christian faith.

In the self-deception - notes Markus Günther - help gleaming facades and strong structure. In this country, there are 45,000 churches,

$6 \quad$ J. Ratzinger, Bóg i świat. Wiara i życie w dzisiejszych czasach, transl. G. Sowiński, Kraków 2001, p. 406.

$7 \quad$ Cf. M. Günther, Kirche in der Krise: Diaspora Deutschland, „Frankfurter Allgemeine Sonntagzeitung” (2014) 52, p. 3. 
Fundamental theology

and most of them - purely structurally - in good condition. This year, the Catholic Church and the Evangelical Church in Germany will receive more money than ever before in history. The German church music is the best in the world. Every year, there are 44,000 Catholic marriages and 225,000 young people celebrate the Protestant confirmation. Is it irrelevant? It is still the argument that Christian churches are the second largest employer in Germany and provide a safe place to work for more than one million people ${ }^{8}$.

Money, strong structures and numerous offers of good job do not provide means for the real power of the religious community. Markus Günther says very bluntly that Christian Churches cannot be reduced to the level of legitimacy of the local waste incineration plant. One cannot treat the religious communities mainly as employers or effective social services. Churches should be seen primarily as communities of faith. Unfortunately, the common confession of faith vanished into thin air. Only one-third of Germans believe in the resurrection of Jesus Christ. $60 \%$ of Catholics and Protestants, formally belonging to their churches and paying church tax, do not believe in an afterlife.

In some regions of Germany, more people believe in UFOs than in the Last Judgement. For the vast majority of Catholic and Protestant religious ceremonies are treated primarily as a part of the family and social tradition. Indeed, in a country on the Rhine different kinds of religious services are still solemnly celebrated, but more often without reference to God - Gottesdienst werden einfach ohne Gott weitergefeiert. Sociological studies show that in 2030 the number of Christians of different denominations in Germany will be a little larger than the community of Jehovah's Witnesses? .

Ibidem.

„Wie wenig die Kirchenmitgliedschaft heute noch mit dem Glauben zu tun hat, offenbarte eine Meinungsumfrage des Instituts Allensbach im Auftrag der katholischen Kirche. Sie fiel allerdings so verheerend aus, dass die Ergebnisse nie veröffentlicht wurden. Auf die Frage, warum sie katholisch seien, antworteten 68 Prozent: «Weil man dann wichtige Ereignisse im Leben kirchlich feiern kann, zum Beispiel Hochzeit, Taufe». Auch beim zweithäufigsten Grund kann man die herzerfrischende Ehrlichkeit nur bewundern: «Es gehört für mich einfach dazu, das hat in unserer Familie Tradition». Es versteht sich von selbst, dass diese Gründe nicht als religiös gelten können, sondern einfach kulturelle, soziale Gründe sind. Die meisten Geistlichen vor Ort können den Befund bestätigen: Kirche funktioniert heute dort am besten, wo sie eine glänzende Feier verspricht. Eine Trauung in Weiß, oft in einer fremden, aber imposanten Kirche, ist immer noch sehr gefragt, ebenso die Bilder vom Kommunionkind im weißen Kleid oder vom Konfirmanden im dunklen Anzug. Doch fast jeder dritte Konfirmand glaubt gar nicht an Gott. [...] Auch viele Gottesdienste sind heute so ausschließlich kulturelle Ereignisse (also: wöchentlicher Treffpunkt, 


\section{Karl Rahner's diagnosis}

Many valuable comments on the state of Christianity in modern times and the diagnosis of atheism generated a German philosopher and theologian Romano Guardini (1885-1968), who very often asked in his incisive writings about the possibility of the Christian faith in a world dominated by technology and "counting thinking". A continuator of his studies at the Ludwig Maximilian University in Munich, was a philosopher and theologian Eugen Biser (1918-2014). Biser referred in one of his books to the vision of the future of Christianity, which has been developed by a well-known German thinker Karl Rahner. Biser called Rahner's proposal "winter diagnosis " (Winter-Diagnose) ${ }^{10}$.

"Winter diagnosis" says about the current difficult stage in the history of Christianity in the Western world, when the followers of this religion live as a minority in atheistic and secularized societies. This does not mean the impossibility of the Christian faith in this kind of conditions, culture and civilization. Rahner was convinced that the more Christianity frees itself from its social and political relations, the more present is its mystical future. The Rahner's concept refers to the views of authors such as Nicholas of Cusa, Blaise Pascal, John Henry Newman and Gertrud von Le Fort.

The essence of Rahner's belief is the claim that the Christian of the future will either be a mystic or he will not exist at all -Christ der Zukunft der wird ein Mystiker sein oder er wird nicht mehr sein. "A pious person in the future will either be a "mystic", someone who "has experienced" something, or he will cease to be pious, since piety of tomorrow will not be supported by the belief coming from the personal experience and decision, natural and public, nor by the religious customs of other people"11.

Rahner very often highlighted in his writngs, that for Christians it is now time of great trial, which is atheism. In an era marked by

jährliche Folklore, Familienfest), dass sie auch nach dem endgültigen Beweis von Gottes Nichtexistenz genauso gut weitergefeiert werden könnten. Die Spätzeit des Christentums in Deutschland hat begonnen. Die Kirchensteuer wird entweder unter politischem Druck abgeschafft oder versiegt spätestens ab 2030 sowieso; die letzte christlich sozialisierte und kirchlich aktive Generation scheidet bald aus dem Arbeitsleben aus und stirbt in den nächsten drei Jahrzehnten. Dann bricht auch die Fassade der Kirche zusammen. Dahinter wird eine Minderheit zum Vorschein kommen, die nicht viel größer sein wird als die Gemeinschaft der Zeugen Jehovas" (ibidem).

10 Cf. E. Biser, Glaubensprognose: Orientierung in postsäkularistischer Zeit, Graz - Wien - Köln 1991, p. 388.

$11 \quad$ K. Rahner, Nuovi saggi, Roma 1968, p. 24. 
Fundamental theology atheism God becomes distant and silent. Atheism and technique make religious experience fade away, which is more often being regarded as a false manifestation of instincts and psychological needs. It is time, in which God is no longer needed for "plugging holes", which said Martin Heidegger. Many mysteries of the world and a man, explained before by God and religion has been expounded through scientific and technological development of our civilization. God is no longer necessary for "plugging holes", which "we discover the inadequacy of our existence" 12 .

What forms of Christian religion are still possible in a world dominated by atheism and technology? Rahner claims that in a completely new reality an act of faith is not something natural. In this situation, different forms of religious life are not a sign of complex and rich piety, typical of antiquity and the Middle Ages, but they are expressions of humble and poor experience of what is transcendent and supernatural. Christians today have to live next to incomprehensible and silent God. "Naked" and modest piety indicates the need for courage for the direct relationship with unspeakable God and for the acceptance of his silent communication.

Rahner distinguished in his writings secularisation from secularism. The essence of secularization is the gradual emancipation of the secular - as a result of the process of secularization a new world order is born, which is subject to desacralisation in accordance with the nucleus of the Christian religion. "We live in a secular world. In this secular world, we have different functions in the material, biological and social in the strict sense dimension, but we also have a plurality of the spiritual aspirations of a man, ideologies, concepts, specific lifestyles, cultures, parties" ${ }^{13}$. Secularization understood in such a way is not the enemy of religion, while secularism is based on the total deprivation of the world of any relationship with Transcendence. Secularism is finally identified with atheism and becomes the enemy of Christianity ${ }^{14}$.

To maintain a living relationship with silent God - in a world dominated by atheistic mentality - Rahner called for the so-called mystagogy of religious experience that reveals the inseparability of natural relation of human existence with absolute mystery of God. Mystagogy

$12 \quad$ Ibidem, p. 21.

13 K. Rahner, Podstawowy wykład wiary, transl. T. Mieszkowski, Warszawa 1987, p. 323.

14 Cf. A. Milano, Secolarizzazione, [in:] Nuovo Dizionario di teologia, G. Barbaglio, S. Dianich eds., Cinisello Balsamo 2000, p. 1438-1466. 
should remove the fear of man in the face of immense and terrifying emptiness and nothingness, when a person begins to call upon God who is unexpressed. From Rahner's perspective, the mystagogy shows that God cannot be so simply to experience, because He is essentially

Incomprehensible. It takes courage to maintain intimacy to God and call Him our "You" even when His abode is remoteness, darkness and Fundamental silence.

Eugen Biser agreed with Rahner that Christianity is faced with the mystical prospect as the only chance of survival. According to Biser, it is the mystique that distinguishes Christianity from other religions.

Obviously, there is mystique in other religions - in Islam, Judaism and the Eastern religions there are mystical traditions - but Eugen Biser says that other religions have mystique, while Christianity is mystique in its very essence. According to him, this is the difference between Christianity and other religions. Christianity is mysticism, while other religions have mystique. How does Eugen Biser explain that Christianity not only has the mystique, but it simply is mysticism? [...] According to him, the fundamental event upon which Christianity is based, it is a fundamental mystical event. The main event of Christianity is the resurrection of Jesus Christ. [...] The crisis of Christianity relies heavily on the fact that the phenomenon of resurrection, which is the basis of Christianity is not analyzed sufficiently in the theological sense and sometimes it is even understood in the physical and biological sense ${ }^{15}$.

\section{Atheism in Denmark, Belgium and the Netherlands}

Karl Rahner's comments on the mystical character of the Christian faith in modern times refer not only to the country on the Rhine, but also to many other societies of the Western world. One such country, deeply affected by atheism, is Denmark. The scale of religious drama in the country clearly reflects a public debate, which swept through Denmark at the beginning of 2015. An interesting exchange of different opinions on religious subjects began with the article, which was published December 25, 2014 by one of the Protestant pastors, Per Ramsdale, in the newspaper "Jyllands-Posten". Pera Ramsdale's statement provoked a lively discussion that lasted several weeks ${ }^{16}$.

15 M. Thurner, Die mystische Dimension bei Eugen Biser und die Mystikerinnen von Helfta, http://www.eugen-biser-stiftung.de/fileadmin/user_upload/Veranstaltungen/Helfta/4_Helfta_Thurner_17072010.pdf, p. 2 (access: 7.06.2016).

16 Cf. R. Meister, Auferstehung? Ja, aber..., „Christ in der Gegenwart“ 68 (2016) 13, p. 137. 
Fundamental theology
What was the problem of the Danish debate? Pastor frankly confessed in his article that he did not believe in the resurrection of Jesus Christ. Moreover, he said that in speaking of the resurrection and eternal life during funeral services - comforting in this way relatives and friends of the dead - he felt like telling the co called innocent white lie, or lie for a good purpose. Several other pastors who presented the same problem sympathized with the author of the article. The discussion in Denmark affected many important philosophical and ideological issues. What is the scale of contemporary atheism? What is today the Danish Protestantism? Which truths of the faith should accept Christian clergymen? What are the effects of progressive secularization of our continent?

Denmark belongs undoubtedly to the group of the most secularized societies of the Western world. The Danish National Church, officially the Evangelical-Lutheran Church of Denmark (Den Danske Folkekirke) - the largest Christian church in the country, having the status of a state church is also affected by deep secularism. The majority of society admits to Protestantism as the state religion, but only $3 \%$ of them practice their religion in a different way. Many of the zealous Protestants left the Danish National Church after 2012, when homosexual "weddings" have been legalized. Denmark is now in the majority atheistic or agnostic society, and the closed churches are reshaped into museums, cafes and modern second hand shops.

There is almost identical situation in Belgium. Society of the country is becoming increasingly atheistic or agnostic. Christianity in Belgium rapidly is dying out, and in its place there comes Islam. Sociological studies clearly show that half of the children in public schools in Brussels is Muslim. Only $1 \%$ of the population of the capital city admits to practice the Catholic religion. Muslims have 77 mosques in Brussels, which are filled to the brim with praying people. Catholics possess 110 churches which are almost empty, and 35 of them were destined for closure in the near future.

The vast majority of inhabitants of Brussels is formally Christians, who often do not practice their religion and become atheists, agnostics or religiously indifferent people. A lot of them can say that they are called cultural Christians who do not believe in personal God, but they accept Christian values and achievements of Western civilization, formed on the foundation of the Gospel. In the cultural sense the predominant religion in Brussels still remains Christianity. When it comes to religious practices and rituals, the most important faith becomes Islam. It seems that the number of Muslims taking part in 
Friday prayers in the mosques, in the great metropolis of Brussels, outnumber all the Christians of different denominations, who gather on Sunday in the city for worship in their temples.

Another European country deeply affected by atheism and secularization, is the Netherlands, which half a century ago belonged to the group of extremely religious and conservative societies of our contiFundamental nent. Almost all of the inhabitants of this country were either practicing Catholics or practicing Protestants. In the late 50th century approx. $90 \%$ of Dutch citizens took seriously their religion and was attached to the traditional Christian morality. Today approx. 70\% of the Dutch has no connection with any religion. Among the atheists and agnostics stands out recently a new group of "Ietsism" and "Somethingism" (nl. Ietsisme), which means that there is not a specified belief in the existence of some unknown transcendent power between heaven and earth, which should not be called God.

In the past 50 years, the Netherlands has become one of the most secular societies in the world - the country of tulips went through in a very short time, a long way from the traditional Christian morality to the new morality in the spirit of the leaders of the sexual revolution of 1968. The Dutch have become a negation of whom they were in the recent past. When it comes to the Catholic community, approx. 18 thousand of believers leave the Church as an institution each year. It is foreseen the closure of one third of Catholic churches by 2020 in the country of tulips, which are successively converted into shops, restaurants, guesthouses or rooms to practice skateboarding.

\section{Mystical overcome atheism}

The dominance of atheism in many European countries raises difficult questions about the future of the Christian religion. The new and difficult situation confronts Christians of different denominations with extremely complex challenges. What form of religious experience is possible today? How to prepare for the coming future? It seems that in the current situation a history of little-known French mystic Madeleine Sémer gains special actuality ${ }^{17}$. Her understanding of the experience of God and the Christian religion can be a great inspiration for Christians living in societies dominated by secular and atheistic mentality. Why? French mystic lived her life in a way parallel to the

17 Cf. F. Klein, Madeleine Sémer convertie et mystique 1874-1921, Paris 1924; idem, Madeleine Sémer (1874-1921). Übersetzung und Nachwort von Romano Guardini, Ostfildern 1952; idem, Madeleine Semer: Convert and Mystic 1874-1921, Whitefish 2010 . 
Fundamental theology

one of Friedrich Nietzsche and struggled personally with the drama of atheism, unbelief and nihilism.

After a childhood marked by intelligent and enthusiastic piety, the religious world was destroyed during adolescence. Young Madeleine lost faith and became an atheist. Her existential skepticism was not nostalgic, but energetic and full of vitality. As a non-believer, blessed with natural beauty and great intelligence, she began her long spiritual and intellectual journey. After much searching she met the philosophy of Nietzsche, which had a huge impact on her. The journey of young Madeleine was similar to the fate of Nietzschean "free spirit", for which skepticism is courage, a manifestation of the will to eliminate everything that is an obstacle to human interaction with the world of things. In this sense, skepticism is a life that has the courage to face reality without barriers and limitations.

Studying the works of Nietzsche, Madeleine Sémer rediscovered Christian faith, which she had previously lost. What's more, she not only deeply understood the author of Thus Spake Zarathustra, but she also lived with him in a way. She was aware of being his companion, being on the same level as in a sense he was. Consequently, Sémer transformed and turned to her mystical experience all that is good in Nietzsche - and she overcame and cleared immanent existence in the Hellenistic style, bringing it into the world of Christian experience.

Romano Guardini claimed that the basic feeling of the woman "was related to her awareness that she was healthy and beautiful. There are still words that express: "perfect health", "perfect balance", inner and outer beauty. Sémer fully realized this belief, even in her existence of faith"18. French mystic introduced world values into her religious experience, which were demanded by Nietzsche. She did not resign from teaching of the cross and suffering, but at the same time she retains a sense of health and beauty, which is a property characterized by her entire existence.

It seems that this kind of attitude is especially valuable in today's dispute with the atheistic mind. For many environments, the Christian message is currently being presented as hostile to freedom and full human life. Atheism or agnosticism very often appears as a form of liberation from the constraints of a religious nature to achieve happiness and fulfillment. Madeleine Sémer showed in her life that Christianity does not preclude happiness and fulfillment. Her authentic Christian mysticism has nothing to do with hostility to life. What's more, French 
mystic was able to appreciate the size of the world and feel its beauty ${ }^{19}$. The mystique of Sémer is saturated with beauty, enjoys the joy of meeting with God and experiencing the fullness of healing in a climate of spiritual intoxication. The inner experience of French mystic proves that it is possible to overcome Nietzsche that takes nothing away from the scandal of the Cross. Madeleine Sémer showed in her life that the Christian religion is not the enemy of happiness and health, but it transforms everything, leading to the complete fulfillment.

\section{Conclusion}

Atheism is the great challenge of the future. In some countries, today one can see very clearly how can look like a world dominated by atheistic thinking, where God is an enemy or an intruder. It seems that today we only see the contours of a world that is coming. It should be noted that the negation of God is not a rare phenomenon in human history. Plato condemned in his works atheism as a "great evil" that corrupts young people in particular. However, atheism as a cultural phenomenon of a massive character is typical for modern times. In the long process of secularization God has been removed from many fields of human activities. The apogee of this process is the work of Friedrich Nietzsche and his shocking words "God is dead".

The development of atheism in Europe and on other continents raises the urgent need for dialogue between Christians of different denominations and groups that question the religious view of the world and a man. Today, more and more is being talked about spirituality and religious sensibility of agnostics and atheists. It seems that this kind of attitude is possible for those who do not share the belief in the existence of any supernatural being, but at the same time feel the limitations of reason and behave in the heart the sense of mystery. In contrast, it is difficult to talk about the religious sensitivities of agnostics or atheists, who are full of prejudices and openly struggling with religion.

Romano Guardini claimed that the religious problem of our time and the times that are coming is to look for opportunities of coexistence of God and the world. Unfortunately, very often religion is regarded as a restriction of our freedom and an obstacle to achieve happiness and fulfillment. It is very important to overcome some of the objections formulated by Nietzsche at Christianity. It is a mistake as to acquaint the world, and neglect of the creative Christian power. Little respect for the value of creativity and initiative in a Christian environment

$19 \quad$ Idem, Il testamento di Gesù, Brescia 1985, p. 167. 
Fundamental theology

is something very disturbing, while overestimating the virtues of accuracy and obedience. In this context, religious experience of Madeleine Sémer becomes extremely valuable, because she claimed that Christianity is not the enemy of life - on the contrary, it helps a man achieve its fullness and happiness.

\section{CZY ATEIZM ZWYCIĘŻA W EUROPIE? PRZYSZŁOŚĆ CHRZEŚCIJAŃSTWA W ŚWIECIE ZACHODNIM}

Głównym celem artykułu jest ukazanie niektórych przejawów wymierania chrześcijaństwa w Europie oraz ukazanie możliwości dalszego trwania religii chrześcijańskiej w tych społeczeństwach, które zostały zdominowane przez postawę obojętności religijnej bądź myślenie ateistyczne czy agnostyczne. Ateizm stanowi niewątpliwie wielkie wyzwanie przyszłości. W niektórych krajach już dzisiaj dominuje kultura określona przez ateistyczną wizję świata i człowieka. Bardzo ciekawe uwagi na temat chrześcijaństwa i ateizmu można znaleźć w pismach niemieckiego myśliciela Karla Rahnera (1904-1984) i francuskiej mistyczki Madeleine Sémer (1874-1921). W dziełach tych dwóch autorów zawiera się niezwykle przenikliwa diagnoza czasów nowożytnych i wizja transformacji religii chrześcijańskiej w świecie zachodnim.

Słowa kluczowe: ateizm, agnostycyzm, chrześcijaństwo, islam, nihilizm, sekularyzacja, doświadczenie religijne.

\section{Bibliography:}

1. Bauer R., Was ist los mit den Christen?, Trier 2013.

2. Biser E., Glaubensprognose: Orientierung in postsäkularistischer Zeit, Graz - Wien - Köln 1991.

3. Guardini R., Pensatori religiosi, Brescia 1977.

4. Guardini R., Il testamento di Gesù, Brescia 1985.

5. Günther M., Kirche in der Krise: Diaspora Deutschland, „Frankfurter Allgemeine Sonntagzeitung" (2014) 52, p. 3.

6. Klein F., Madeleine Sémer convertie et mystique 1874-1921, Paris 1924.

7. Klein F., Madeleine Sémer (1874-1921). Übersetzung und Nachwort von Romano Guardini, Ostfildern 1952.

8. Klein F., Madeleine Semer: Convert and Mystic 1874-1921, Whitefish 2010.

9. Meister R., Auferstehung? Ja, aber..., „Christ in der Gegenwart“ 68 (2016) 13, p. 137.

10. Meotti G., Dio è morto in Germania, „Il Foglio Quotidiano” 20 (2015) 264, p. 3.

11. Milano A., Secolarizzazione, [in:] Nuovo Dizionario di teologia, G. Barbaglio, S. Dianich ed., Cinisello Balsamo 2000, p. 1438-1466. 
12. Nietzsche F., Zapiski o nihilizmie (z lat 1885-1889), [in:] Wokót nihilizmu, G. Sowiński ed., Kraków 2001, p. 73-110.

13. Rahner K., Nuovi saggi, Roma 1968.

14. Rahner K., Podstawowy wykład wiary, transl. T. Mieszkowski, Warszawa 1987.

15. Ratzinger J., Sól ziemi. Chrześcijaństwo i Kościót katolicki na przełomie theology tysiacleci, transl. G. Sowiński, Kraków 1997.

16. Ratzinger J., Bóg i świat. Wiara $i$ życie $w$ dzisiejszych czasach, transl. G. Sowiński, Kraków 2001.

17. Repole R., Così parlò Nietzsche: Dio è morto?, „Archivio Teologico Torinese" 10 (2004) 1, p. 53-67.

18. Thurner M., Die mystische Dimension bei Eugen Biser und die Mystikerinnen von Helfta, http://www.eugen-biser-stiftung.de/fileadmin/user_upload/ Veranstaltungen/Helfta/4_Helfta_Thurner_17072010.pdf.

19. Żelazna J., Narodziny nihilizmu - epoka mitu, epoka prawdy, „Toruński Przegląd Filozoficzny" 3/4 (2000), p. 57-81. 